\title{
The Baatho-Assadist System, a System of Political Instrumentalisation
}

\author{
Samira Mobaied \\ SU Sorbonne Université, Muséum national d'Histoire naturelle, IRD, Patrimoines locaux, environnement et globalisation \\ (PALOC, UMR 208), Paris, France \\ Email: mobaied@mnhn.fr
}

How to cite this paper: Mobaied, S. (2020). The Baatho-Assadist System, a System of Political Instrumentalisation. Open Journal of Political Science, 10, 124-133.

https://doi.org/10.4236/ojps.2020.101009

Received: December 20, 2019

Accepted: January 14, 2020

Published: January 17, 2020

Copyright $\odot 2020$ by author(s) and Scientific Research Publishing Inc. This work is licensed under the Creative Commons Attribution International License (CC BY 4.0).

http://creativecommons.org/licenses/by/4.0/

\begin{abstract}
Various studies on political instrumentalisation show its application in several areas as an element of political recovery of all forms of protest in favour of power. In this context, this study analyses the different facades of the political instrumentalisation of the Syrian political system. The instrumentalisation of civil society, the instrumentalisation of education, the instrumentalisation of Syrian constitution, the instrumentalisation of secularism and religions, the instrumentalisation of opposition, the instrumentalisation of the Palestinian-Israeli conflict and Arab nationalism, the instrumentalisation of media and the instrumentalisation of culture and of space and cities have been analysed. Syria is considered to be a country subject to a single party that monopolises political activity within the state the Baath Party, the only political party standing for election, and the only one governing the country continuously since 1963; all the elements analysed in this study show that instrumentalisation is a fundamental method of the Syrian political system. It is used systematically and methodically.
\end{abstract}

\section{Keywords}

Syria, Political Instrumentalisation, Baath, Assad

\section{Introduction}

Instrumentalisation as defined by Marc Uhalde, a sociology researcher, is the diversion of a process or object towards purposes other than those initially conceived, an illegitimate diversion with regard to the values or normative conceptions implicit in the process (Uhalde, 2008). This diversion leads to a political recovery of all forms of protest in favour of power, according to John D. H. Downing, a communications specialist; it is a subversive plagiarism that diverts language and images from their intended use (Downing, 2000). 
The various studies on political instrumentalisation show its application in several areas, defined by the sociologist Yannick Barthe as a process of gaining access to the political sphere for a particular cause, a technical subject or a social problem which previously had not been treated politically (Garcier et al., 2017). Religions are among the most instrumentalised fields. In this context, Jean-Philippe Platteau, researcher at the Centre of Research for Development Economics (CRED), talks about the political instrumentalisation of Islam (Platteau, 2011), Florian Bieber, researcher at the European Centre for Minority Issues, shows an example of the instrumentalisation of minorities in Montenegro (Bieber, 2002). Other researchers have revealed the instrumentalisation of culture and art for political gain and even the instrumentalisation of history and ethnicity (Faye, 1994).

In this context, this study analyses the different facades of the political instrumentalisation of the Syrian political system. Syria is considered a country subject to a single party that monopolises political activity within the state, the Baath Party, the only political party standing for election, and the only one governing the country continuously since 1963. A constitutional amendment in 1973 gave the Baath Party exceptional status as a "party leading the state and society" in Syria until the introduction of the new Syrian constitution in February 2012 (Belhadj, 2014). The Assad regime is considered to be a minority regime, as described by Fabrice Balanche, adjoint professor of political geography and director of research, as "being a sect in power" (Balanche, 2006) because the military coup of 1963 was the initiative of a group of officers who belong mainly to religious minorities (Alawites, Druze, Ismaili and Christians). However, a few years later, the Alawites expelled the other minority groups from key positions, and in 1970, Hafez al-Assad's military coup was carried out on an Alawite community basis with his clan. He eliminated the founders of the Baath Party, and transformed the party into a tool to conquer power and dominate the institutions of state.

The leaders of the Baath Party (14 members in total) are the highest officials in Syria, led by Hafez al-Assad at the head of the state and the Baath Party until his death in 2000 when Bashar al-Assad Hafez's son inherited power and the Baath Party from his father.

During these five decades, the Assad clan "instrumentalised" the Baath Party and the army in order to perpetuate their power. They were placed in all the key positions across the country, locking the system down with a highly effective intelligence network, according to the study by geographer Michael F. Davie (Davie, 2006).

The Baath Party instrumentalised by the Assad clan uses the same logic of instrumentalisation to dominate Syria, over the control of the population by the party's organisations and by its propaganda.

A number of arguments may explain the way in which the Baath Party instrumentalises state institutions, civil society, ethnic groups and religions, space and territories, as well as a series of social, political and economic processes to 
assert its domination over Syria. Analysis of those elements will be the primary objective of this study. Lastly, the research discusses how political instrumentalisation is a fundamental method of this system; it is used systematically and methodically.

\section{The Instrumentalisation of Civil Society}

Nazih Ayubi, a political scientist and professor at the University of Exeter, described the Baath system as a corporatist system, because Syria, dominated by the Baath Party, exemplifies a model of "state-centred corporatism". This single party has, since 1963, succeeded in dominating civil society through the formation or takeover of unions, professional and sectoral associations affiliated to the Baath (Ayubi, 1996).

Several examples illustrate these developments since 1963, because, to take power, the Baath Party has instrumentalised trade union oppression and used violence, the iron fist and class struggle as part of its strategy to marginalise the feudal class and the capitalists, in order to consolidate its authority. It has reorganised the institutions of state and created a wide range of organisations to contain and control sectors of society. It has put the Syrian state on a path of development hostile to capitalism and, at the same time, does not carry the spirit of socialism. Its objective was the construction of power and not the state as Steven Heydemann, Professor of Middle East Studies and Director of the Middle East Studies Programme at Smith College, explains in his book "Authoritarianism in Syria" (Heydemann, 2018).

\subsection{The Pioneers of the Baath Party}

Talaaee Al Baath, The Baath Vanguards, is a Syrian government organisation founded in 1974 by Hafez al-Assad, which brings together Syrian children aged between 6 and 11 years old from elementary schools, and which has dominated all extracurricular activities, leisure centres and sports competitions for Syrian school children since its establishment. Membership of this organisation is mandatory, parents are not asked for their opinion, because all students are considered pioneers of the Baath Party under this political system.

\subsection{The Revolutionary Youth Union}

The Revolutionary Youth Union is a Syrian governmental organisation founded in 1970 by Hafez al-Assad, based on the ideology of the Baath Party, to shape the youth of Syria from the age of 12 to 18 years under the domination of the Baath Party. It has replaced all other associations and centres for youth, except for churches, such as the Scout Movement which the Baath regime banned in Syria upon its arrival in power.

\subsection{The General Union of Syrian Women}

Syrian feminist associations existed before the Baath Party came to power, and 
were involved in remarkable activities, for example in 1930 the first Congress of Oriental Women was held in Damascus to demand a series of reforms in the spirit of gender equality.

The Assad regime has gathered together the women's movement and feminist associations and created the General Union of Syrian Women to promote the ideology of Baath, and the Assad regime has allowed a feminist group to be active in Syria. This is the Al Qubeissiat group; an Islamic fundamentalism group that supports it.

\section{The Instrumentalisation of Education}

Raymon Al-Maaloli, a university professor and educational researcher in Syria, conducted a study on the ideology of authority during 50 years of education in Syria. He concludes that since coming to power, the Baath Party has dominated and instrumentalised the education system, and education policy has become directly linked to politics, with the objective of reproducing and maintaining the dominant political and economic system of the Baath (Al-Maaloli, 2016).

For five decades, Baath Party slogans repeated daily to children in all Syrian schools, photographs of Hafez al-Assad and the Baath Party logo were heavily used in all classes and offices of all schools in the country, including private schools, as well as in school textbooks and notebooks, as a way to unify society under the control of the Baathist and Assad system installed at the pinnacle of the state and the Baath Party.

\section{The Instrumentalisation of the Syrian Constitution}

The Constitution of the Syrian Arab Republic, adopted by referendum on 12 March 1973, gave the Baath Party (or Socialist Party of the Arab Resurrection) a key role in political life.

Since 1973 the legislative authority, represented by the parliament, has been totally dominated by the Baath Party, because the members of the People's Assembly are elected via lists drawn up by the Baath Party and the National Front, under the control of the intelligence services. Consequently, these are absurd elections that do not represent the real will of the people.

The new constitution of the Republic was adopted by the referendum of 26 February 2012 and differs from that of 1973 in that there is no reference to a political party, but in the 2012 Constitution the President uniquely encompasses all powers, from the executive to the legislative and judicial branches, and the executive power represented by the President of the Republic, therefore, assumes all three powers, through the articles stipulated between Articles (from 83 - 150) of the 2012 constitution.

There are some examples of this:

Article 101: The President of the Republic shall pass decrees, decisions and orders in accordance with the laws.

Article 103: The President of the Republic declares the state of emergency and 
repeals it in a decree taken at the Council of Ministers chaired by him with a two-thirds majority, provided that the decree is presented to the People's Assembly in its first session. The law sets out the relevant provisions.

Article 107: The President of the Republic concludes international treaties and agreements and revokes them in accordance with provisions of the Constitution and rules of international law.

Article 108: The President of the Republic grants special amnesty and might reinstate individuals.

Article 111: 1. The President of the Republic might decide to dissolve the People's Assembly in a justified decision he makes.

Article 113 1. The President of the Republic assumes the authority of legislation when the People's Assembly is not in session, or during sessions if absolute necessity requires this, or in the period during which the Assembly is dissolved.

Article 133: 1. The Supreme Judicial Council is headed by the President of the Republic; and the law states the way it shall be formed, its mandate and its rules of procedures.

And Article 150 1. The President of the Republic, and so does a third of the members of the People's Assembly, might propose amending the Constitution.

\section{The Instrumentalisation of Secularism and Religions}

The Assad Baathist regime presents itself as the guarantor of secularism in Syria and claims to be a progressive secular regime (Taha, 2012a). The fraudulent use of secularism has been demonstrated by several researchers including Zakaria Taha, in his article entitled "Le parti Baath et la dynastie al-Asad en Syrie: la laïcité dans un contexte communautaire" [The Baath Party and the al-Asad dynasty in Syria: secularism in a community context] in which he shows that secularism has been manipulated by the leaders of the Baath Party whose primary objective is to maintain power.

During the Baath-Assad period, Islam became a source of legitimacy for a non-Sunni president in his quest for legitimacy. Assad began to take steps to spread Islam, which led to a re-Islamisation of society. The Constituent Assembly accepted certain demands from Islamic circles, imposing a Muslim head of state and stating that "Islamic doctrine was the primary source of legislation".

The instrumentalisation of minorities is also mentioned in Taha's works, since the confrontation with the Muslim Brotherhood in the 1980s, the regime has presented itself as a bulwark against the Islamist threat likely to dominate minorities (Druze, Christians, Kurds, Ismaili) (Taha, 2012b). After the revolution, Assad used these community instruments to prevent minorities from joining in the protests against it, collusion between Islamic groups and the Assad regime emerged, the Assad regime took advantage of Islamist groups and terrorism for its own purposes and with the aim of consolidating its domination over the country, spreading hatred and generating fear and mistrust (Mobaied, 2019). 


\section{The Instrumentalisation of the Opposition}

No new Syrian opposition political parties have emerged since the mid-70s, according to Yassin Hajj-Saleh, a Syrian writer and one of the intellectuals opposed to the Assad regime, Hajj-Saleh speaks in his article "L'opposition syrienne" [The Syrian opposition] (Al Hajj-Saleh, 2003) of three principal axes of opposition, the first being the traditional political parties of the Syrian opposition including the Communist Party and the Muslim Brotherhood. The second brings together civil society actors, and the third is the National Progressive Front (pro-government) because the Baath Party has controlled and instrumentalised the opposition (within Syria) for decades by bringing these opponents together within the National Progressive Front, a grouping of legal, political parties aligned with the regime (Taha, 2012b).

Meanwhile, internal, popular or political oppositions outside this political framework tolerated by Assad were crushed. Despite Baath's violent repression of the Muslim Brotherhood, even this conflict was instrumental in strengthening the repression of political freedom and freedom of expression. This conflict, which escalated in 1980, was the beginning of the annihilation of civil society and all independent political life (Al Hajj-Saleh, 2003). The vast campaign of repression and arrests that was launched in the late 1970s targeted not only the Muslim Brotherhood, but also the entire Sunni community and, in passing, the troublesome rivals for power: communists, pro-Iraqi and Nasserian Baathists according to (Benkorich, 2012).

Since these events, the Baath Party has begun to construct the inner enemy according to a strategy of building the enemy, unmasked by Michel Seurat (Seurat, 2012) and Matthieu Cimino, developed in the following paragraph. This figure of the enemy was also present at the heart of the counter-revolutionary repression launched in March 2011 and the theme of the foreign "enemy", deployed by the Baath Party, was present in its counter-revolutionary strategy. According to Kachee and Maucourant, in 2016, the Syrian regime was able to construct useful enemies to deny the revolutionary nature of the popular movement through which Syria had passed.

\section{The Instrumentation of the Palestinian-Israeli Conflict and Arab Nationalism}

The goal of the Baath Party, identified by the unification of the different Arab states into a single great nation, is the ideology of Arab nationalism, Leyla Dakhli, shown in her article entitled "Arabism, Arab Nationalism and Transnational Arab Identifications in the 20th Century", published in 2009 in Vingtième Siècle. Reviewing history, this Arab nationalism, favoured by the designation of enemies to face (the European imperialist states, the State of Israel), and by the collapse of other frames of reference (the Ottoman Empire, the Caliphate, the Mediterranean of the Levant scales, etc.), has long been frozen in authoritarian regimes that have confiscated it and made it a weapon to fight any opposition, be it 
communist or Islamist (Dakhli, 2009).

Since the domination of Baath in power, Assad has been the Arab leader of resistance against Israel, basing his discourse on the exogenous threat of enemies, and the feeling of being besieged by enemies, many of whom are manufactured by the propaganda of the Baath system, being, therefore, a tool for submission to power.

Based on a study entitled "Le pathos négatif en tant que trait du discours politique totalitaire" (Kacprzak, 2013) [Negative pathos as a feature of totalitarian political discourse] by Alicja Kacprzak, a specialist in sociolinguistics and discourse analysis and lecturer at the Department of Philology at the University of Lod, Matthieu Cimino analysed, in his article, the "Fabrique de l'ennemi" [Inventing the enemy] in a totalitarian regime. The case of Syria (1946-2014), the enemy's construction strategy used by the Syrian authorities, in this analysis shows that the Baath Party bases its survival strategy on the systematic invention and maintenance of a competing otherness that has to be fought. When Hafez al-Assad, a member of the Alawi minority, came to power, he had no legitimacy among a Sunni population and believed that the preservation of the Israeli enemy must remain the key element of the regime's arsenal for survival. The instrumentalisation of the State of Israel as a vehicle for nationalist affirmation is a Baathist weapon (Cimino, 2014) and has therefore served the survival of the regime.

\section{The Instrumentalisation of Media and Culture}

Ali Safar, a Syrian poet and journalist, in his testimony on the situation of intellectuals under the Baatho-Assadist regime (Alcheikh, 2018) explains that Hafez al-Assad was confronted by Syrian intellectuals upon coming to power, most of whom were opponents of his political regime, who were either leftists, Syrian nationalists, Liberals or Islamists.

According to Saffar, intellectuals and culture, in general, had to "change their spots" under the Baathist regime and stay away from the reality of political life in Syria and also from cultural development on a global scale. Ali Safar, like other intellectuals, witnessed the transformation of the cultural situation into a void. In the same article, Assad Ferzat, a Syrian painter talks about cultural and visual pollution during the time of the Assad regime, when the Syrian imagination was destroyed in the propaganda and image of the tyrant "gods".

Ibrahim Al-Jabin, Syrian intellectual and writer shows that the regime has made its own intellectuals on sectarian and opportunist criteria; Al-Jabin has unmasked their sectarian discourse in his book/novel Orients Oculus "Ain Ash-Sharq" (Al-Jabin, 2017). It also explains how these Assad intellectuals have supported this totalitarian regime since the beginning of the demonstrations by justifying the bombings and genocides that the regime has committed and accusing the Syrian people of ignorance, barbarism and intimidation of the world and calling it possible terrorism. This idea of Pseudo-Intellectuals also appears in 
the work of Tzvetan Todorov, historian of ideas and former director of the Centre for Research on Arts and Language (CRAL, CNRS-EHESS), explained in his book entitled "La Peur des barbares: Au-delà du choc des civilisations" [The fear of barbarians: beyond the clash of civilisations], that the "Truth" is sacrificed in a totalitarian country to the struggle for victory (Todorov, 2008).

\section{The Instrumentalisation of Space and Cities}

The notion of space is a complex notion that is included in the political or institutional domain through the control of landscape as a modality for the territorialisation of dominant groups and political institutions (Debarbieux, 2007). In this context, the territorial analysis of the Syrian revolt, carried out by Fabrice Balanche (Balanche, 2011), reflects the instrumentalisation of all the spaces where society is organised by the communitarianism that structures Syrian society and the Assad regime itself. In his 2005 article entitled "La fragmentation spatiale en Syrie" [Spatial fragmentation in Syria] (Balanche, 2005) Balanche explains the imbalances in the Syrian economic space linked to pre-Baathist spatial structures, in which the peripheries are subjected to or assisted by the Baathist political structure.

\section{Conclusion}

All the elements analysed in this study show that instrumentalisation is a fundamental method of the Syrian political system. It is used systematically and methodically to incorporate and subjugate the whole of Syrian society, a process that has enabled it to remain in power for five decades and that must be clearly identified and taken into account to continue the trajectory of change in Syria.

There may be also other elements that are not yet fully investigated which may explain the way in which the Baath Party dominated the state and civil society. Today, the Baath Party lost much of its authority, leadership, and support base; there is an opportunity to improve our understanding of the mechanisms used to put totalitarian philosophy into practice which has not been a conscious concern in much of this work.

\section{Conflicts of Interest}

The author declares that they have no conflict of interest.

\section{References}

Al Hajj-Saleh, Y. (2003). L’opposition syrienne. Confluences Méditerranée, No. 44, 71-81. https://doi.org/10.3917/come.044.0071

Alcheikh (2018). How Culture Became a Tool of Assad. Consulted on Almodon.com Aug, 2018.

Al-Jabin, I. (2017). Orients Oculus (Ain ash-sharq, عبن الثرق). Beirut: Arab Institute for Research \& Publishing.

Al-Maaloli, R. (2016). The Ideology of Authority: 50 Years of Education in Syria. Washington DC: Fikra Forum, Initiative of the Washington Institute. 
Ayubi, N. N. (1996). Over-Stating the Arab State: Politics and Society in the Middle East. New York: I.B. Tauris.

Balanche, F. (2005). La fragmentation spatiale en Syrie. Revuede l'Economie Méridionale, Centre régional de la productivité et des études économiques, 53, 7.

Balanche, F. (2006). Les Alaouites: Une secte au pouvoir. Outre Terre, No. 2, 73-96. https://doi.org/10.3917/oute.014.0073

Balanche, F. (2011). Geographie de la revolte syrienne. Outre-Terre, No. 29, 437-458. https://doi.org/10.3917/oute.029.0437

Belhadj, S. (2014). L'appareil sécuritaire syrien, socle d'un régime miné par la guerre civile. Confluences Méditerranée, No. 89, 15-27. https://doi.org/10.3917/come.089.0015

Benkorich, N. (2012). Trente ans après, retour sur la tragédie de Hama. Published on La vie des idées, Feb. 2012. Consulted on laviedesidees.fr.

Bieber, F. (2002). The Instrumentalization of Minorities in the Montenegrin Dispute over Independence. European Centre for Minority Issues (ECMI).

Cimino, M. (2014). La "fabrique de l'ennemi" en système totalitaire. Le cas syrien (1946-2014). Relations internationals, No. 158, 117-135. https://doi.org/10.3917/ri.158.0117

Dakhli, L. (2009). Arabisme, nationalisme arabe et identifications transnationales arabes au 20e siècle. Vingtième Siècle. Revue d'histoire, No. 103, 12-25.

https://doi.org/10.3917/ving.103.0012

Davie, M. F. (2006). Le Cadre Alaouite II Cellule familiale versus appartenance sectaire. Outre-terre, No. 14, 97-104. https://doi.org/10.3917/oute.014.0097

Debarbieux, B. (2007). Actualité politique du paysage. Journal of Alpine Research/Revue de géographie alpine, 101-114. https://doi.org/10.4000/rga.382

Downing, J. D. H. (2000). Radical Media. Newbury Park, CA: SAGE Publications, Inc.

Faye, O. (1994). L'instrumentalisation de l'histoire et de l'ethnicité dans le discours séparatiste en Basse Casamance (Sénégal). Africa Spectrum, 29, 65-77.

Garcier, R., Martinais, E., \& Rocher, L. (2017). Naming, Measuring and Controlling: the Politics of Flows and "Circulations". Geocarrefour.

https://doi.org/10.4000/geocarrefour.12079

Heydemann, S. (2018). Authoritarianism in Syria. Ithaca, NY: Cornell University Press. https://doi.org/10.7591/9781501725616

Kachee, A., \& Maucourant, J. (2016). La Syrie entre révolutions et ingérences. Astérion, No. 14. https://doi.org/10.4000/asterion.2730

Kacprzak, A. (2013). Le pathos négatif en tant que trait du discours politique totalitaire. Argumentation et analyse du discours. No. 10. https://doi.org/10.4000/aad.1427

Mobaied, S. (2019). Colloque La France et le Moyen-Orient. [Online], Collège de France, 22/03/2019.

https://www.college-de-france.fr/site/henry-laurens/symposium-2019-03-22-08h45.htm

Platteau, J. P. (2011). Political Instrumentalization of Islam and the Risk of Obscurantist Deadlock. World Development, 39, 243-260.

https://doi.org/10.1016/j.worlddev.2009.11.028

Seurat, M. (2012). Syrie: L'Etat de barbarie (p. 288). Paris: Presses Universitaires de France. https://doi.org/10.3917/puf.seura.2012.01

Taha, Z. (2012a). Le parti Baath et la dynastie al-Asad en Syrie: La lä̈cité dans un contexte communautaire. ffhalshs-00734773f., June 2012. 
Taha, Z. (2012b). L'opposition kurde et le régime du Baath en Syrie: Entre dynamique identitaire et stratégies de cooptation. Aix-en-Provence, France: Oppositions partisanes en situation autoritaire. Jun 2012, Aix-en-Provence, France. ffhalshs-00734750f.

Todorov, T. (2008). La Peur des barbares: Au-delà du choc des civilizations. Paris: Robert Laffont.

Uhalde, M. (2008). L'instrumentalisation de la sociologie en situation d'intervention: Analyse critique d'une notion ordinaire. Sociologies pratiques, No. 16, 95-113.

https://doi.org/10.3917/sopr.016.0095 